\title{
Chronic primary pain in the COVID-19 pandemic
}

Citation for published version (APA):

Meulders, A., Vlaeyen, J. W. S., Evers, A. W. M., Köke, A. J. A., Smeets, R. J. E. M., Van Zundert, J. H. M., Verbunt, J. M. C. F., \& Van Ryckeghem, D. M. L. (2022). Chronic primary pain in the COVID-19 pandemic: how uncertainty and stress impact on functioning and suffering. Pain, 163(4), 604-609. https://doi.org/10.1097/j.pain.0000000000002428

Document status and date:

Published: 01/04/2022

DOI:

10.1097/j.pain.0000000000002428

Document Version:

Publisher's PDF, also known as Version of record

Document license:

Taverne

Please check the document version of this publication:

- A submitted manuscript is the version of the article upon submission and before peer-review. There can be important differences between the submitted version and the official published version of record.

People interested in the research are advised to contact the author for the final version of the publication, or visit the DOI to the publisher's website.

- The final author version and the galley proof are versions of the publication after peer review.

- The final published version features the final layout of the paper including the volume, issue and page numbers.

Link to publication

\footnotetext{
General rights rights.

- You may freely distribute the URL identifying the publication in the public portal. please follow below link for the End User Agreement:

www.umlib.nl/taverne-license

Take down policy

If you believe that this document breaches copyright please contact us at:

repository@maastrichtuniversity.nl

providing details and we will investigate your claim.
}

Copyright and moral rights for the publications made accessible in the public portal are retained by the authors and/or other copyright owners and it is a condition of accessing publications that users recognise and abide by the legal requirements associated with these

- Users may download and print one copy of any publication from the public portal for the purpose of private study or research.

- You may not further distribute the material or use it for any profit-making activity or commercial gain

If the publication is distributed under the terms of Article $25 \mathrm{fa}$ of the Dutch Copyright Act, indicated by the "Taverne" license above, 


\title{
Chronic primary pain in the COVID-19 pandemic: how uncertainty and stress impact on functioning and suffering
}

\author{
Ann Meulders ${ }^{a, b, *}$, Johan W.S. Vlaeyen ${ }^{a, b}$, Andrea W.M. Evers ${ }^{c, d}$, Albère J.A. Köke, f, , , Rob J.E.M. Smeets ${ }^{f, h}$,
} Jan H.M. Van Zundert ${ }^{\mathrm{i}, \mathrm{j}}$, Jeanine M.C.F. Verbunt ${ }^{\mathrm{e}, \mathrm{f}}$, Dimitri M.L. Van Ryckeghem ${ }^{\mathrm{a}, \mathrm{k}, \mathrm{l}}$

\section{Introduction}

COVID-19 is a highly infectious disease caused by the severe acute respiratory syndrome (SARS)-CoV-2. ${ }^{40}$ Owing to the virus' rapid spread across the globe, the World Health Organization (WHO) declared it a pandemic in March 2020. As such, COVID19 has become a major societal concern, not least because of the large number of infections, the potential severity of the disease, and the mounting death toll worldwide. The COVID-19 pandemic has affected many people's lives and health, with potential longterm consequences. Notably, the detrimental impact of this pandemic is not limited to physical health. For some, the uncertainty and lack of control imposed by this pandemic may lead to increased stress levels, (health) anxiety, and worry, which may further negatively affect mental health and general well-being of both infected and noninfected people. ${ }^{118}$ In addition, the restrictions enforced to contain the virus (eg, physical distancing) and to minimize the burden on the healthcare system further disrupt our social lives and prevent people from connecting with each other, causing loneliness, and in turn negatively affecting health and well-being. ${ }^{6,53}$

Sponsorships or competing interests that may be relevant to content are disclosed at the end of this article.

a Experimental Health Psychology, Maastricht University, Maastricht, the Netherlands, ${ }^{b}$ Research Group Health Psychology, KU Leuven, Leuven, Belgium, ${ }^{c}$ Faculty of Social and Behavioral Sciences, Leiden University, Leiden, the Netherlands, ${ }^{a}$ Leiden Institute for Brain \& Cognition, Leiden University, Leiden, the Netherlands, ${ }^{e}$ Adelante Centre of Expertise in Rehabilitation and Audiology, Hoensbroek, the Netherlands, ${ }^{f}$ Department Rehabilitation Medicine, Research School CAPHRI, Maastricht University, Maastricht, the Netherlands, ${ }^{g}$ Faculty Physical Therapy, Zuyd University of Applied Sciences, Heerlen, the Netherlands, ${ }^{n}$ CIR Revalidatie, Eindhoven, the Netherlands, ${ }^{i}$ Department of Anesthesiology and Pain Medicine, Maastricht University Medical Centre+, Maastricht, the Netherlands, ${ }^{j}$ Department of Anesthesiology, Critical Care, Emergency Medicine and Multidisciplinary Pain Centre, Ziekenhuis Oost Limburg, Genk/Lanaken, Belgium, ${ }^{k}$ Department of Behavioural and Cognitive Sciences, University of Luxembourg, Esch-sur-Alzette, Luxembourg, ' Department of Experimental-Clinical and Health Psychology, Ghent University, Ghent, Belgium

${ }^{*}$ Corresponding author. Address: Faculty of Psychology and Neuroscience, Experimental Health Psychology, Maastricht University, P.O. Box 616, 6200 MD Maastricht, the Netherlands. Tel.: +3143388 33 97. E-mail address: ann.meulders@kuleuven.be (A. Meulders).

Supplemental digital content is available for this article. Direct URL citations appear in the printed text and are provided in the HTML and PDF versions of this article on the journal's Web site (www.painjournalonline.com).

PAIN 00 (2021) 1-6

(C) 2021 International Association for the Study of Pain

http://dx.doi.org/10.1097/j.pain.00000000000002428
People suffering from persistent pain represent a vulnerable group at risk to be disproportionately affected by the COVID-19 pandemic and its measures. First, the reduced access to health care and suspension of routine pain management can exacerbate chronic pain disability. ${ }^{25}$ Second, uncertainty may prime increased attention to bodily sensations and pain, ${ }^{29}$ increasing health anxiety, and catastrophic worry, especially in those who are intolerant of uncertainty or those lacking effective coping strategies (eg, seeking support), some of which are unavailable because of the safety measures. ${ }^{84}$ Third, to avoid contamination, physical distancing often boils down to complete self-isolation in individuals with chronic illness; isolation inevitably leads to reduced participation in daily activities and thus increases disability, ${ }^{75}$ as well as it decreases health behaviors and reduces physical activity worsening health outcomes. ${ }^{28}$ Finally, high-stress situations increase suffering and psychological distress in individuals with chronic pain, eg, in the aftermath of terrorist attacks, ${ }^{72}$ as well as reducing self-rated mental health after the first lockdown. ${ }^{28}$

In this review, we propose a conceptual framework describing how COVID-19 may affect modifiable factors resulting in worsened health outcomes and disability in people with chronic pain. We cautiously suggest strategies targeting these modifiable factors and how these can help to guide treatment and reduce the negative impact of the current pandemic. We present a model (Fig. 1) outlining how the impact of known risk factors in the development and maintenance of chronic pain may become more pronounced during a pandemic because of increased uncertainty, perceived uncontrollability, COVID-related stress, and paradoxically by contagion-reducing safety behaviors. Furthermore, other precautions to contain the spread of COVID-19 (eg, physical distancing) may compromise resilience factors (eg, positive affect, optimism, and social support), which may hamper daily functioning and participation of people with chronic pain. Finally, this model aims to inspire future research aimed at a better understanding of how to reduce negative long-term effects of the COVID-19 pandemic in people with chronic pain and prevent patients who are still functioning from becoming severely disabled. ${ }^{51,113}$

\section{COVID-19: an "invisible" and uncertain health threat}

Common symptoms of COVID-19 are fever, fatigue, persistent dry cough, and anosmia; more severe symptoms include chest pain and shortness of breath, but it can even result in life-threatening circumstances needing ICU admission, followed by severe speech and motor problems (WHO, https://www.who.int/health-topics/ coronavirus). Although initially viewed as a respiratory disease, 
INTENSITY OF STRESS-INDUCING EVENT
PREDISPOSING VULNERABILITIES AND RESILIENCIES
OUTCOMES

OUTCOS

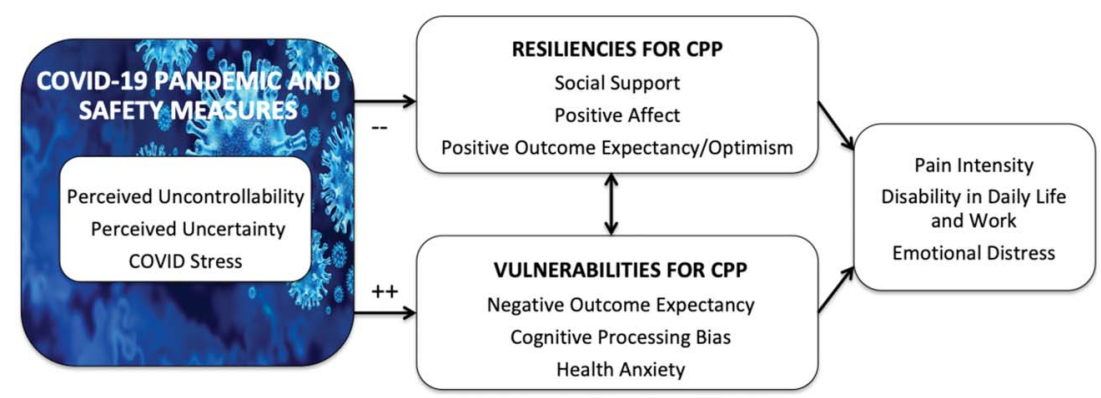

Figure 1. Theoretical model showing how risk factors for the development and maintenance of chronic pain disability in daily life and work may be triggered or amplified by uncertainty, uncontrollability, and intensity of COVID-related stress, and these COVID-related factors and safety measures may compromise resilience factors affecting long-term health outcomes such as pain intensity, emotional distress (including, but not limited to, fear, anxiety, sleep disturbance or insomnia, depression, and helplessness), and disability in daily life and work (including domains such as family/home responsibilities, recreation, social activity, occupation, sexual behavior, and self-care).

increasing evidence indicates that COVID-19 can affect multiple systems (eg, cardiac, renal, and neurological) and cause multidomain impairment, fatigue, and chronic pain. ${ }^{15,55}$ The variable symptom presentation and the overlap with other conditions impede straightforward diagnosis of COVID-19. Eighty percent of infections are mild or asymptomatic, though still contagious, fueling the spread of the disease. ${ }^{9}$ Furthermore, owing to the long incubation period, people who present themselves without symptoms can be transmitting the virus, thus posing a potential threat for infection. This, in combination with insufficient diagnostic testing and the observation that only $10 \%$ of the population produces antibodies, ${ }^{9}$ increases the risk of (re-)infection. To date, uncertainty exists about the newly developed vaccines (in terms of long-term protection, potential side effects, and availability) and the choice to get vaccinated. There is no cure for COVID-19, and except for some risk factors (eg, obesity, age $>60$, underlying medical conditions, or compromised immune system), our understanding of for whom the infection will lead to hospitalization or death is limited. This makes COVID-19 an invisible threat to our health, causing high levels of uncertainty. This uncertainty is further fueled by nonstop media coverage, often providing conflicting information, as well as contradicting recommendations by public health authorities in different countries, which fosters "uncertainty distress."13 Increased social media exposure brimming with conspiracy theories ${ }^{10}$ further triggers COVID-related fear and worry. ${ }^{29,52,64,116,117}$ Finally, uncertainty about the future in general, such as the unknown long-term socioeconomic consequences and unknown duration and likelihood of resurgence of the pandemic, contributes to COVID-related stress and anxiety.

On top of that, the measures taken to slow the spread of the virus impede the sense of being in control of our own lives. For example, imposed lockdowns, curfews, and restricting the use of recreational facilities and public spaces may increase helplessness, ${ }^{90}$ anxiety, and stress, ${ }^{69}$ which may further affect negatively on health and well-being.

\section{Chronic primary pain: a particularly vulnerable group}

Chronic primary pain (CPP) is a prevalent health problem affecting about $20 \%$ of the population, leading to personal suffering and putting a huge strain on our healthcare system and society. ${ }^{74}$ Owing to the lacking underlying anatomic cause of their pain, this group is characterized by diagnostic uncertainty, ${ }^{91}$ which may be inflated by the current COVID-related uncertainty, increasing functional impairment and distress. Therefore, we will use CPP as a prototype throughout our review. People suffering from chronic pain may be at risk of disease severity when infected with SARSCoV-2 because the prevalence of chronic pain in elderly is higher and they also have increased levels of comorbidity, ${ }^{23}$ both known risk factors for COVID-19. Chronic pain has also been associated with immunosuppression, often caused or exacerbated by opioid and steroids use ${ }^{92}$; this implicates that people with chronic pain using opioids or steroids could potentially be more susceptible to COVID-19 and have difficulties to combat the virus. In addition the increased vulnerability for severe COVID-19 illness, individuals with CPP also suffer disproportionally from the measures taken to contain COVID-19, including suspension of routine pain management. ${ }^{25}$ This is widely recognized by the pain community, reflected, for example, in the European Pain Federation (EFIC) COVID-19 Task Force initiative providing information and advice, as well as the call for continued treatment and e-health alternatives to treat chronic pain during the pandemic. ${ }^{16,25,92}$ In addition, enforced measures potentially compromise resilience factors, such as positive affect, optimism, positive outcome expectancies, and social support, ${ }^{14}$ further hampering daily functioning in this vulnerable group. Indeed, research during the first COVID-19 lockdown showed that individuals with chronic pain were more adversely affected compared with pain-free people, showing greater increase in anxiety, depression, loneliness, as well as self-perceived pain. ${ }^{30}$ Undeniably, individuals with CPP are increasingly prone to suffer severe consequences from both COVID-19 and the taken containment measures, which may culminate into augmented levels of stress.

\section{COVID-related stress and vulnerability for chronic primary pain: the perfect storm?}

Contemporary pain models assign a key role to psychosocial factors in the development and maintenance of chronic pain and augmented levels of disability and distress. ${ }^{18,26,110,112}$ Among others, health anxiety, ${ }^{42,43,87}$ cognitive-processing biases for pain and pain-related information, particularly attention ${ }^{27}$ and interpretation biases, ${ }^{56,57,108}$ and proneness towards negative outcome expectancies $^{101}$ (eg, overgeneralization ${ }^{65,66,111}$ and 
catastrophic worry ${ }^{103}$ ) have often been considered vulnerabilities contributing to pain-related disability in CPP. ${ }^{102}$

Indeed, a wealth of research has shown that negative outcome expectancies are associated with poor pain outcomes. In this context, catastrophic worry has emerged as one of the best psychosocial predictors of pain, distress, and disability. ${ }^{27,54,82}$ Catastrophic worry may exert its detrimental effects through several pathways, such as inducing an aroused, negative emotional state exacerbating pain or prompting helplessness which in turn decreases adaptive pain responding. ${ }^{62}$ Its causal status is further confirmed by studies investigating the processes of change in pain management programs in which reducing catastrophic worry arose as a crucial factor for treatment success. ${ }^{5,11-13,93,103}$ In addition, accumulating evidence suggests that people with chronic pain overgeneralize expectancy of pain outcomes and pain-related fear to technically safe stimuli $^{45,46,66,67}$ and that it takes longer for them to update these expectancies and fear when presented with disconfirming information compared with healthy, pain-free controls. ${ }^{68,104}$ Obviously, protective responses (pain-related fear and avoidance) are adaptive when they prevent further bodily harm, but when they spread to a myriad of safe activities or situations, they may paradoxically compromise daily functioning, leading to disability.

Furthermore, the prevailing biopsychosocial models of chronic pain postulate that interpreting ambiguous bodily sensations as threatening as well as heightened attention (ie, hypervigilance) for pain and pain-related stimuli may drive disability. ${ }^{19,99,106}$ Abundant research demonstrates that people with chronic pain show both a greater tendency to attend to pain and pain-related information (attention bias ${ }^{20,100}$ ) and interpret ambiguous stimuli as threatening (interpretation bias ${ }^{89}$ ), whereby these biases are believed to be underlying poor pain outcomes and maintenance of chronic pain. . $^{5,81}$

Finally, severe and disabling levels of health anxiety have been estimated at $51 \%$ for clinic attenders with chronic pain ${ }^{87}$ and have been associated with poor prognosis. ${ }^{42}$ Health anxiety is characterized by catastrophic misinterpretation of bodily sensations, disease conviction, dysfunctional beliefs about health or illness, and maladaptive coping behaviors (eg, reassurance seeking and checking behaviors), which provide relief in the short run but paradoxically perpetuate the dysfunctional beliefs in the long run. Anxiety has been also found to increase nocebo-related effects of negative outcome expectancies in pain. ${ }^{98}$ In particular, high levels of health anxiety also have been reported to increase safety behaviors in people with chronic low back pain, ${ }^{96}$ which can be considered a maintaining factor of erroneous beliefs and disability. In the context of the COVID-19 pandemic, people with increased health anxiety might engage in maladaptive safety behaviors, such as excessive hand washing, social withdrawal, and panic purchasing. ${ }^{3}$ Although these actions seem harmless, they may paradoxically worsen stress and anxiety ${ }^{107}$ and may have a detrimental impact on others in the community (eg, unnecessary hoarding of hand sanitizer, protective gear, and medication).

Crucially, the impact of each of these vulnerabilities is strongly defined by contextual features. Particularly, the presence of heightened stress and uncertainty, typical in times of COVID-19 (see supra), may strongly increase the impact of described vulnerabilities on increased disability. In this context, the prevailing diathesis-stress model conceptualizes "diatheses" as dormant individual vulnerabilities present that are triggered and worsened by stress ${ }^{21}$ (Fig. 1). Undoubtedly, current times of extreme uncertainty induced by the global pandemic qualify as stressful life events able to awaken or amplify the expression of pre-existing vulnerabilities. Obviously, evidence in the context of COVID-19 to date is largely lacking. Yet, evidence from experimental research suggests that these factors can indeed be increased by uncertainty, lack of control, and stress.

For example, uncontrollability is associated with perceived helplessness and cortisol elevation, ${ }^{22,73}$ confirming that it triggers the human stress response, which may in turn induce cognitiveaffective sensitization of pain. Other studies have shown that uncontrollability directly increases suffering, but not necessarily pain intensity. ${ }^{61}$ Similarly, uncertainty has been shown to induce hyperalgesic effects in pain perception, and individuals with higher harm vigilance (combined catastrophic worry, trait anxiety, avoidance behavior, and emotional instability) showed stronger spinal facilitation, which in turn contributed more to the observed hyperalgesia. ${ }^{97}$ Furthermore, catastrophic worry has been shown to increase by (experimentally induced) stress ${ }^{7,109}$ and can be conceptualized as an emotion regulation strategy to decrease the negative affect arising from stressful situations. ${ }^{34}$ In the same vein, stress typically narrows attention to salient environmental cues, consequently enhancing vigilance and attention to potentially threatening stimuli. ${ }^{4}$ Cognitive processing biases thus are expected to be stronger under stressful circumstances. ${ }^{70,71,88}$ Finally, also health anxiety can be amplified by stressful life events such as being ill or suffering from the loss of a significant other. ${ }^{2}$

\section{COVID-19 pandemic and safety measures compromise resilience factors}

By contrast, social support, ${ }^{41,63}$ optimism ${ }^{39}$ and positive outcome expectancies, ${ }^{17}$ and positive affect ${ }^{31,77}$ protect against the negative impact of chronic pain on disability and distress. ${ }^{94}$ Positive affect and optimism execute their bolstering effect ${ }^{44}$ through broadening attention towards positive stimuli and revoking cognitive processing biases, ${ }^{35,114}$ undoing the detrimental effect of negative emotions, ${ }^{36}$ reducing overgeneralization of fear and pain outcome expectancy, ${ }^{37}$ and tackling catastrophic worry. ${ }^{76}$ On the other hand, isolation, loneliness, and lacking social support may worsen stress ${ }^{78}$ and increase disability, ${ }^{75}$ whereas social support is associated with better adaptation to chronic pain and increased well-being. Owing to the COVID-related uncertainty and stress, the situation of people with CPP may worsen or propel the transition from a manageable situation into a crippling condition when protective factors are removed and the buffering effect against the existing vulnerabilities is withdrawn.

\section{Targets for clinical practice and prevention}

The provided theoretical framework has important consequences for the treatment of people with CPP during a pandemic. Indeed, based on this framework, we argue that healthcare providers should be attentive for increased levels of stress, perceived uncertainty, and uncontrollability in CPP because they may boost the expression of vulnerability factors, resulting in increased pain, distress, and disability. Nowadays, a plethora of interventions are available to do so, ranging from simple, such as clear communication and providing unambiguous information, ${ }^{33,83}$ full-fetched add-on uncertainty and stress management interventions ${ }^{38}$ to cognitive-behavioral therapy, whereby reduced uncertainty is established by promoting beneficial use of emotion regulation, self-management skills, and psychoeducation. In addition, protocols targeting intolerance of uncertainty that have mainly been developed and proven efficacious in the context of 
psychopathology (eg, generalized anxiety disorders) $8,24,60,86,105,115$ may be translated to and implemented in the context of the pandemic. Finally, acceptance-based and mindfulness-based techniques may be used to reduce the negative impact of uncertainty by increasing tolerance of uncertainty $^{50}$ and increasing psychological flexibility. These strategies may not only affect uncertainty, health anxiety, and perceived COVID-related stress by altering the appraisal of uncertainty from danger to opportunity or acceptance ${ }^{85}$ but also downregulate pain ${ }^{58}$ and stress-related biomarkers. ${ }^{49}$

Our framework additionally urges to strengthen resilience, which may be compromised by not only enforced measures to contain the spread of COVID-19 but also COVID-related stress and perceived uncertainty. A broad range of possibilities is available varying from very simple, eg, increasing social connectedness online to combat loneliness, ${ }^{53}$ to more extensive techniques, such as full-blown positive psychology interventions focusing on increasing positive affect or optimism. ${ }^{80}$ In addition, increased positive affect broadens attention towards positive stimuli ${ }^{35,36,114}$ and thereby tackling hypervigilance for bodily symptoms and sensations. ${ }^{44}$ Finally, increased psychological resilience through boosting positive emotions predicts decreases in catastrophic worry. ${ }^{76}$ Further research is needed to validate our theoretical model because there is an urgent need to develop (and evaluate) specific interventions in the context of the current pandemic.

\section{Future research directions and conclusion}

The current COVID-19 pandemic and the enforced measures to contain the virus brings along great uncertainty, lack of control, and COVID-related stress. People with CPP may be especially at risk to suffer disproportionately under these circumstances. We used CPP as a prototypic pain diagnosis, but this model may be extended or applied to other chronic pain diagnoses (eg, arthritis, cancer, and diabetes) and even to subacute or new-onset pain. In our conceptual framework, perceived uncertainty, uncontrollability, and elevated stress levels may awaken or amplify known vulnerabilities for chronic pain disability (such as, but not limited to, negative outcome expectancies, cognitive processing biases, and health anxiety) and compromise resilience factors (eg, positive affect, positive outcome expectancies, optimism, and social support) leading to worsened mental health outcomes and increased disability. We have argued that healthcare professionals should consider targeting these factors in treatment and foster strategies to prevent pandemic-induced worsened outcomes in CPP. Our model is not exhaustive and other factors may be worth investigating, such as the differential impact in different stages or waves of the pandemic; individual differences such as trait intolerance of uncertainty and social anxiety; and more distal factors such as sex, ${ }^{47}$ economic stress, ${ }^{59}$ education, and race, which may moderate the outcomes in our model. Furthermore, the provided framework does not specify how the pandemic may affect factors evolving across the lifespan (eg, social roles) and how this affects pain outcomes. Exhaustive research from a developmental perspective, spanning from pediatrics to geriatrics, is warranted to answer these questions. These future findings could then complement the current framework. Finally, the COVID-19 pandemic may impede physical activity and exercise which is associated with reduced mental health ${ }^{1,28,79}$ and sleep which affect described mental health outcomes as well as pain and interference directly. ${ }^{32,48,95}$ Therefore interventions aiming to restore sleep and physical exercise may also be considered as treatment options.

\section{Conflict of interest statement}

The authors have no conflicts of interest to declare.

\section{Acknowledgements}

A. Meulders supported by a Vidi grant from the Netherlands Organization for Scientific Research (NWO), the Netherlands (grant ID 452-17-002). J.W.S. Vlaeyen is supported by the Asthenes research program "From Acute Aversive Sensations to Chronic Bodily Symptoms," a long-term structural Methusalem funding (METH/15/011) by the Flemish government, Belgium. D.M.L. Van Ryckeghem is supported by the FNR Core Junior programme (Painflex; Nr. 12671141).

\section{Supplemental video content}

A video abstract associated with this article can be found at http:// links.Iww.com/PAIN/B449.

\section{Article history:}

Received 20 December 2020

Received in revised form 1 July 2021

Accepted 2 July 2021

Available online 2 August 2021

\section{References}

[1] Alvaro PK, Roberts RM, Harris JK. A systematic review assessing bidirectionality between sleep disturbances, anxiety, and depression. Sleep 2013;36:1059-68.

[2] Asmundson GJ, Abramowitz JS, Richter AA, Whedon M. Health anxiety: current perspectives and future directions. Curr Psychiatry Rep 2010; 12:306-12

[3] Asmundson GJG, Taylor S. How health anxiety influences responses to viral outbreaks like COVID-19: what all decision-makers, health authorities, and health care professionals need to know. J Anxiety Disord 2020;71:102211.

[4] Baddeley AD. Selective attention and performance in dangerous environments. Br J Psychol 1972;63:537-46.

[5] Besen E, Gaines B, Linton S, Shaw WS. The role of pain catastrophizing as a mediator in the work disability process following acute low back pain. J Appl Biobehavioral Res 2017;22:e12085

[6] Brooks SK, Webster RK, Smith LE, Woodland L, Wessely S, Greenberg N, Rubin GJ. The psychological impact of quarantine and how to reduce it: rapid review of the evidence. Lancet 2020;395:912-20.

[7] Brosschot JF, Gerin W, Thayer JF. The perseverative cognition hypothesis: a review of worry, prolonged stress-related physiological activation, and health. J Psychosom Res 2006;60:113-24.

[8] Buhr K, Dugas MJ. Investigating the construct validity of intolerance of uncertainty and its unique relationship with worry. J Anxiety Disord 2006; 20:222-36

[9] Buitrago-Garcia D, Egli-Gany D, Counotte MJ, Hossmann S, Imeri H, Ipekci AM, Salanti G, Low N. Occurrence and transmission potential of asymptomatic and presymptomatic SARS-CoV-2 infections: a living systematic review and meta-analysis. PLoS Med 2020;17:e1003346.

[10] Burki T. The online anti-vaccine movement in the age of COVID-19. Lancet Digital Health 2020;2:e504-5.

[11] Burns JW, Day MA, Thorn BE. Is reduction in pain catastrophizing a therapeutic mechanism specific to cognitive-behavioral therapy for chronic pain? Transl Behav Med 2012;2:22-9.

[12] Burns JW, Glenn B, Bruehl S, Harden RN, Lofland K. Cognitive factors influence outcome following multidisciplinary chronic pain treatment: a replication and extension of a cross-lagged panel analysis. Behav Res Ther 2003;41:1163-82.

[13] Burns JW, Kubilus A, Bruehl S, Harden RN, Lofland K. Do changes in cognitive factors influence outcome following multidisciplinary treatment for chronic pain? A cross-lagged panel analysis. J Consult Clin Psychol 2003;71:81-91.

[14] Che X, Cash R, Ng SK, Fitzgerald P, Fitzgibbon BM. A systematic review of the processes underlying the main and the buffering effect of social support on the experience of pain. Clin J Pain 2018;34:1061-76. 
[15] Clauw DJ, Häuser W, Cohen SP, Fitzcharles MA. Considering the potential for an increase in chronic pain after the COVID-19 pandemic. PAIN 2020;161:1694-7.

[16] Cohen SP, Baber ZB, Buvanendran A, McLean BC, Chen Y, Hooten WM, Laker SR, Wasan AD, Kennedy DJ, Sandbrink F, King SA, Fowler IM, Stojanovic MP, Hayek SM, Phillips CR. Pain management best practices from multispecialty organizations during the COVID-19 pandemic and public health crises. Pain Med 2020;21:1331-46.

[17] Colloca L, Barsky AJ. Placebo and nocebo effects. N Engl J Med 2020; 382:554-61.

[18] Crombez G, Eccleston C, Van Damme S, Vlaeyen JW, Karoly P. Fearavoidance model of chronic pain: the next generation. Clin J Pain 2012; 28:475-83.

[19] Crombez G, Van Damme S, Eccleston C. Hypervigilance to pain: an experimental and clinical analysis. PAIN 2005;116:4-7.

[20] Crombez G, Van Ryckeghem DM, Eccleston C, Van Damme S. Attentional bias to pain-related information: a meta-analysis. PAIN 2013;154:497-510.

[21] Dersh J, Polatin PB, Gatchel RJ. Chronic pain and psychopathology: research findings and theoretical considerations. Psychosom Med 2002;64:773-86.

[22] Dickerson SS, Kemeny ME. Acute stressors and cortisol responses: a theoretical integration and synthesis of laboratory research. Psychol Bull 2004;130:355-91.

[23] Dominick CH, Blyth FM, Nicholas MK. Unpacking the burden: understanding the relationships between chronic pain and comorbidity in the general population. PAIN 2012;153:293-304.

[24] Dugas MJ, Brillon P, Savard P, Turcotte J, Gaudet A, Ladouceur R, Leblanc R, Gervais NJ. A randomized clinical trial of cognitive-behavioral therapy and applied relaxation for adults with generalized anxiety disorder. Behav Ther 2010;41:46-58.

[25] Eccleston C, Blyth FM, Dear BF, Fisher EA, Keefe FJ, Lynch ME, Palermo TM, Reid MC, Williams ACC. Managing patients with chronic pain during the COVID-19 outbreak: considerations for the rapid introduction of remotely supported (eHealth) pain management services. PAIN 2020;161:889-93.

[26] Eccleston C, Crombez G. Worry and chronic pain: a misdirected problem solving model. PAIN 2007;132:233-6.

[27] Edwards RR, Cahalan C, Calahan C, Mensing G, Smith M, Haythornthwaite JA. Pain, catastrophizing, and depression in the rheumatic diseases. Nat Rev Rheumatol 2011;7:216-24.

[28] Elran-Barak R, Mozeikov M. One month into the reinforcement of social distancing due to the COVID-19 outbreak: subjective health, health behaviors, and loneliness among people with chronic medical conditions. Int J Environ Res Public Health 2020;17:5403.

[29] Faasse K, Porsius JT, Faasse J, Martin LR. Bad news: the influence of news coverage and google searches on Gardasil adverse event reporting. Vaccine 2017;35:6872-8.

[30] Fallon N, Brown C, Twiddy H, Brian E, Frank B, Nurmikko T, Stancak A. Adverse effects of COVID-19 related lockdown on pain, physical activity and psychological wellbeing in people with chronic pain. 2021;5: 357-68.

[31] Finan PH, Garland EL. The role of positive affect in pain and its treatment. Clin J Pain 2015;31:177-87.

[32] Finan PH, Goodin BR, Smith MT. The association of sleep and pain: an update and a path forward. J Pain 2013;14:1539-52.

[33] Finset A, Bosworth H, Butow P, Gulbrandsen P, Hulsman RL, Pieterse $A H$, Street $R$, Tschoetschel $R$, van Weert J. Effective health communication-a key factor in fighting the COVID-19 pandemic. Patient Educ Couns 2020;103:873-6.

[34] Flink IL, Boersma K, Linton SJ. Pain catastrophizing as repetitive negative thinking: a development of the conceptualization. Cogn Behav Ther 2013;42:215-23.

[35] Fredrickson BL, Branigan C. Positive emotions broaden the scope of attention and thought-action repertoires. Cogn Emot 2005;19:313-32.

[36] Fredrickson BL, Mancuso RA, Branigan C, Tugade MM. The undoing effect of positive emotions. Motiv Emot 2000;24:237-58.

[37] Geschwind N, Meulders M, Peters ML, Vlaeyen JW, Meulders A. Can experimentally induced positive affect attenuate generalization of fear of movement-related pain? J Pain 2015;16:258-69.

[38] Gil KM, Mishel MH, Belyea M, Germino B, Porter LS, Clayton M. Benefits of the uncertainty management intervention for African American and white older breast cancer survivors: 20-month outcomes. Int J Behav Med 2006;13:286-94.

[39] Goodin BR, Bulls HW. Optimism and the experience of pain: benefits of seeing the glass as half full. Curr Pain Headache Rep 2013;17:329.

[40] Gorbalenya AE, Baker SC, Baric RS, de Groot RJ, Drosten C, Gulyaeva AA, Haagmans BL, Lauber C, Leontovich AM, Neuman BW, Penzar D,
Perlman S, Poon LLM, Samborskiy DV, Sidorov IA, Sola I, Ziebuhr J. Coronaviridae Study Group of the International Committee on Taxonomy of Viruses. The species severe acute respiratory syndromerelated coronavirus: classifying 2019-nCoV and naming it SARS-CoV-2. Nat Microbiol 2020;5:536-44.

[41] Goubert L, Trompetter H. Towards a science and practice of resilience in the face of pain. Eur J Pain 2017;21:1301-15

[42] Hadjistavropoulos HD, Hadjistavropoulos T. The relevance of health anxiety to chronic pain: research findings and recommendations for assessment and treatment. Curr Pain Headache Rep 2003;7:98-104.

[43] Hadjistavropoulos HD, Janzen JA, Kehler MD, Leclerc JA, Sharpe D, Bourgault-Fagnou MD. Core cognitions related to health anxiety in selfreported medical and non-medical samples. J Behav Med 2012;35: 167-78.

[44] Hanssen MM, Peters ML, Boselie JJ, Meulders A. Can positive affect attenuate (persistent) pain? State of the art and clinical implications. Curr Rheumatol Rep 2017;19:80.

[45] Harvie DS, Moseley GL, Hillier SL, Meulders A. Classical conditioning differences associated with chronic pain: a systematic review. J Pain 2017;18:889-98

[46] Harvie DS, Weermeijer JD, Olthof NA, Meulders A. Learning to predict pain: differences in people with persistent neck pain and pain-free controls. PeerJ 2020;8:e9345.

[47] Hruschak V, Flowers KM, Azizoddin DR, Jamison RN, Edwards RR, Schreiber KL. Cross-sectional study of psychosocial and pain-related variables among patients with chronic pain during a time of social distancing imposed by the coronavirus disease 2019 pandemic. PAIN 2021;162:619-29.

[48] Jahrami H, BaHammam AS, Bragazzi NL, Saif Z, Faris M, Vitiello MV. Sleep problems during the COVID-19 pandemic by population: a systematic review and meta-analysis. J Clin Sleep Med 2021;17: 299-313.

[49] Järvelä-Reijonen E, Puttonen S, Karhunen L, Sairanen E, Laitinen J, Kolehmainen M, Pihlajamäki J, Kujala UM, Korpela R, Ermes M, Lappalainen $\mathrm{R}$, Kolehmainen $\mathrm{M}$. The effects of acceptance and commitment therapy (ACT) intervention on inflammation and stress biomarkers: a randomized controlled trial. Int J Behav Med 2020;27: 539-55.

[50] Johnson Wright L, Afari N, Zautra A. The illness uncertainty concept: a review. Curr Pain Headache Rep 2009;13:133-8.

[51] Jordan KP, Sim J, Croft P, Blyth F. Pain that does not interfere with daily life-a new focus for population epidemiology and public health? PAIN 2019;160:281-5.

[52] Jungmann SM, Witthöft M. Health anxiety, cyberchondria, and coping in the current COVID-19 pandemic: which factors are related to coronavirus anxiety? J Anxiety Disord 2020;73:102239.

[53] Karos K, McParland JL, Bunzli S, Devan H, Hirsh A, Kapos FP, Keogh E, Moore D, Tracy LM, Ashton-James CE. The social threats of COVID-19 for people with chronic pain. PAIN 2020;161:2229-35.

[54] Keefe FJ, Rumble ME, Scipio CD, Giordano LA, Perri LM. Psychological aspects of persistent pain: current state of the science. J Pain 2004;5: 195-211.

[55] Kemp HI, Corner E, Colvin LA. Chronic pain after COVID-19: implications for rehabilitation. Br J Anaesth 2020;125:436-40.

[56] Keogh E, Cochrane M. Anxiety sensitivity, cognitive biases, and the experience of pain. J Pain 2002;3:320-9.

[57] Keogh E, Hamid R, Hamid S, Ellery D. Investigating the effect of anxiety sensitivity, gender and negative interpretative bias on the perception of chest pain. PAIN 2004;111:209-17.

[58] Kober H, Buhle J, Weber J, Ochsner KN, Wager TD. Let it be: mindful acceptance down-regulates pain and negative emotion. Soc Cogn Affect Neurosci 2019;14:1147-58.

[59] Law EF, Zhou C, Seung F, Perry F, Palermo TM. Longitudinal study of early adaptation to the coronavirus disease pandemic among youth with chronic pain and their parents: effects of direct exposures and economic stress. PAIN 2021;162:2132-44.

[60] Li J, Gao J, Zhang Q, Li C, Cui L. The efficacy of intolerance of uncertainty intervention on anxiety and its mediating role by multilayer linear model analysis. J Psychopathol Behav Assess 2021;43:142-51.

[61] Löffler M, Kamping S, Brunner M, Bustan S, Kleinböhl D, Anton F, Flor H. Impact of controllability on pain and suffering. Pain Rep 2018;3:e694.

[62] Lumley MA, Cohen JL, Borszcz GS, Cano A, Radcliffe AM, Porter LS, Schubiner H, Keefe FJ. Pain and emotion: a biopsychosocial review of recent research. J Clin Psychol 2011;67:942-68.

[63] Meints SM, Edwards RR. Evaluating psychosocial contributions to chronic pain outcomes. Prog Neuropsychopharmacol Biol Psychiatry 2018;87:168-82. 
[64] Mertens G, Gerritsen L, Duijndam S, Salemink E, Engelhard IM. Fear of the coronavirus (COVID-19): predictors in an online study conducted in March 2020. J Anxiety Disord 2020;74:102258.

[65] Meulders A. Fear in the context of pain: lessons learned from 100 years of fear conditioning research. Behav Res Ther 2020;131:103635.

[66] Meulders A, Harvie DS, Bowering JK, Caragianis S, Vlaeyen JW, Moseley GL. Contingency learning deficits and generalization in chronic unilateral hand pain patients. J Pain 2014;15:1046-56.

[67] Meulders A, Jans A, Vlaeyen JW. Differences in pain-related fear acquisition and generalization: an experimental study comparing patients with fibromyalgia and healthy controls. PAIN 2015;156:108-22.

[68] Meulders A, Meulders M, Stouten I, De Bie J, Vlaeyen JW. Extinction of fear generalization: a comparison between fibromyalgia patients and healthy control participants. J Pain 2017;18:79-95.

[69] Mineka S, Hendersen RW. Controllability and predictability in acquired motivation. Annu Rev Psychol 1985;36:495-529.

[70] Mogg K, Bradley BP, Hallowell N. Attentional bias to threat: roles of trait anxiety, stressful events, and awareness. Q J Exp Psychol A 1994;47: 841-64.

[71] Mogg K, Mathews A, Bird C, Macgregor-Morris R. Effects of stress and anxiety on the processing of threat stimuli. J Pers Soc Psychol 1990;59: 1230-7.

[72] Moric M, Buvanendran A, Lubenow TR, Mehta A, Kroin JS, Tuman KJ. Response of chronic pain patients to terrorism: the role of underlying depression. Pain Med 2007;8:425-32.

[73] Müller MJ. Helplessness and perceived pain intensity: relations to cortisol concentrations after electrocutaneous stimulation in healthy young men. Biopsychosoc Med 2011;5:8

[74] Nicholas M, Vlaeyen JWS, RiefW, Barke A, Aziz Q, Benoliel R, Cohen M, Evers S, Giamberardino MA, Goebel A, Korwisi B, Perrot S, Svensson P, Wang SJ, Treede RD; IASP Taskforce for the Classification of Chronic Pain. The IASP classification of chronic pain for ICD-11: chronic primary pain. PAIN 2019;160:28-37.

[75] Oliveira VC, Ferreira ML, Morso L, Albert HB, Refshauge KM, Ferreira $\mathrm{PH}$. Patients' perceived level of social isolation affects the prognosis of low back pain. Eur J Pain 2015;19:538-45.

[76] Ong AD, Zautra AJ, Reid MC. Psychological resilience predicts decreases in pain catastrophizing through positive emotions. Psychol Aging 2010;25:516-23.

[77] Ong AD, Zautra AJ, Reid MC. Chronic pain and the adaptive significance of positive emotions. Am Psychol 2015;70:283-4.

[78] Ozbay F, Johnson DC, Dimoulas E, Morgan CA, Charney D, Southwick S. Social support and resilience to stress: from neurobiology to clinical practice. Psychiatry (Edgmont) 2007;4:35-40.

[79] Paluska SA, Schwenk TL. Physical activity and mental health: current concepts. Sports Med 2000;29:167-80.

[80] Parks AC, Boucher EM. Positive Psychological Interventions (PPIs) in the age of COVID-19: on the potential impact of digital PPIs on loneliness. J Positive Psychol 2020;15:569-71.

[81] Pincus T, Morley S. Cognitive-processing bias in chronic pain: a review and integration. Psychol Bull 2001;127:599-617.

[82] Quartana PJ, Campbell CM, Edwards RR. Pain catastrophizing: a critical review. Expert Rev Neurother 2009;9:745-58.

[83] Reddy BV, Gupta A. Importance of effective communication during COVID-19 infodemic. J Fam Med Prim Care 2020;9:3793-6.

[84] Rettie H, Daniels J. Coping and tolerance of uncertainty: predictors and mediators of mental health during the COVID-19 pandemic. Am Psychol $2021 ; 76: 427-37$

[85] Rhodes A, Martin S, Guarna J, Vowles K, Allen T. A contextualbehavioral perspective on chronic pain during the COVID-19 pandemic and future times of mandated physical distancing. J Contextual Behav Sci 2020;17:152-8.

[86] Robichaud M, Dugas MJ. A cognitive-behavioral treatment targeting intolerance of uncertainty. In: Worry and its psychological disorders. Chichester, United Kingdom: John Wiley and Sons, Ltd., 2006. p. 289-304.

[87] Rode S, Salkovskis P, Dowd H, Hanna M. Health anxiety levels in chronic pain clinic attenders. J Psychosom Res 2006;60:155-61.

[88] Rued HA, Hilmert CJ, Strahm AM, Thomas LE. The influence of stress on attentional bias to threat: an angry face and a noisy crowd. Psychon Bull Rev 2019;26:943-50.

[89] Schoth DE, Liossi C. Biased interpretation of ambiguous information in patients with chronic pain: a systematic review and meta-analysis of current studies. Health Psychol 2016;35:944-56.

[90] Seligman ME. Learned helplessness. Annu Rev Med 1972;23:407-12.

[91] Serbic D, Pincus T, Fife-Schaw C, Dawson H. Diagnostic uncertainty, guilt, mood, and disability in back pain. Health Psychol 2016;35:50-9.
[92] Shanthanna H, Strand NH, Provenzano DA, Lobo CA, Eldabe S, Bhatia A, Wegener J, Curtis K, Cohen SP, Narouze S. Caring for patients with pain during the COVID-19 pandemic: consensus recommendations from an international expert panel. Anaesthesia 2020;75:935-44.

[93] Smeets RJ, Vlaeyen JW, Kester AD, Knottnerus JA. Reduction of pain catastrophizing mediates the outcome of both physical and cognitivebehavioral treatment in chronic low back pain. J Pain 2006;7:261-71.

[94] Sturgeon JA, Zautra AJ. Resilience: a new paradigm for adaptation to chronic pain. Curr Pain Headache Rep 2010;14:105-12.

[95] Tang NK. Insomnia co-occurring with chronic pain: clinical features, interaction, assessments and possible interventions. Rev Pain 2008;2: 2-7.

[96] Tang NK, Salkovskis PM, Poplavskaya E, Wright KJ, Hanna M, Hester J. Increased use of safety-seeking behaviors in chronic back pain patients with high health anxiety. Behav Res Ther 2007;45:2821-35.

[97] Taylor VA, Chang L, Rainville P, Roy M. Learned expectations and uncertainty facilitate pain during classical conditioning. PAIN 2017;158: 1528-37.

[98] Thomaidou MA, Veldhuijzen DS, Meulders A, Evers AWM. An experimental investigation into the mediating role of pain-related fear in boosting nocebo hyperalgesia. PAIN 2021;162:287-99.

[99] Todd J, Sharpe L, Johnson A, Nicholson Perry K, Colagiuri B, Dear BF. Towards a new model of attentional biases in the development, maintenance, and management of pain. PAIN 2015;156:1589-600.

[100] Todd J, van Ryckeghem DML, Sharpe L, Crombez G. Attentional bias to pain-related information: a meta-analysis of dot-probe studies. Health Psychol Rev 2018;12:419-36.

[101] Turk DC. A cognitive-behavioral perspective on treatment of chronic pain patients. In: Turk DC, Gatchel RJ, editors. Psychological approaches to pain management: a practitioner's handbook. 2nd ed. New York: Guilford, 2002.

[102] Turk DC, Okifuji A. Psychological factors in chronic pain: evolution and revolution. J Consult Clin Psychol 2002;70:678-90.

[103] Turner JA, Holtzman S, Mancl L. Mediators, moderators, and predictors of therapeutic change in cognitive-behavioral therapy for chronic pain. PAIN 2007;127:276-86.

[104] Van den Bergh O, Brosschot J, Critchley H, Thayer JF, Ottaviani C. Better safe than sorry: a common signature of general vulnerability for psychopathology. Perspect Psychol Sci 2021;16:225-46.

[105] van der Heiden C, Muris P, van der Molen HT. Randomized controlled trial on the effectiveness of metacognitive therapy and intolerance-of-uncertainty therapy for generalized anxiety disorder. Behav Res Ther 2012;50:100-9.

[106] Van Ryckeghem DML, Noel M, Sharpe L, Pincus T, Van Damme S. Cognitive biases in pain: an integrated functional-contextual framework. PAIN 2019;160:1489-93.

[107] van Vliet CM, Meulders A, Vancleef LMG, Vlaeyen JWS. The opportunity to avoid pain may paradoxically increase fear. J Pain 2018;19:1222-30.

[108] Vancleef LM, Hanssen MM, Peters ML. Are individual levels of pain anxiety related to negative interpretation bias? An examination using an ambiguous word priming task. Eur J Pain 2016;20:833-44.

[109] Verkuil B, Brosschot JF, Gebhardt WA, Thayer JF. When worries make you sick: a review of perseverative cognition, the default stress response and somatic health. J Exp Psychopathology 2010;1:jep.009110.

[110] Vlaeyen JW, Crombez G, Linton SJ. The fear-avoidance model of pain. PAIN 2016;157:1588-9.

[111] Vlaeyen JW. Learning to predict and control harmful events: chronic pain and conditioning. PAIN 2015;156(suppl 1):S86-93.

[112] Vlaeyen JW, Linton SJ. Fear-avoidance model of chronic musculoskeletal pain: 12 years on. PAIN 2012;153:1144-7.

[113] Von Korff M, Ormel J, Keefe FJ, Dworkin SF. Grading the severity of chronic pain. PAIN 1992;50:133-49.

[114] Wadlinger HA, Isaacowitz DM. Positive mood broadens visual attention to positive stimuli. Motiv Emot 2006;30:87-99.

[115] Wells A, Welford M, King P. Papageorgiou C, Wisely J, Mendel E. A pilot randomized trial of metacognitive therapy vs applied relaxation in the treatment of adults with generalized anxiety disorder. Behav Res Ther 2010;48:429-34

[116] Winters W, Devriese S, Eelen P, Veulemans H, Nemery B, Van den Bergh O. Symptom learning in response to odors in a single odor respiratory learning paradigm. Ann N Y Acad Sci 2001;933:315-8.

[117] Witthöft M, Rubin GJ. Are media warnings about the adverse health effects of modern life self-fulfilling? An experimental study on idiopathic environmental intolerance attributed to electromagnetic fields (IEI-EMF). J Psychosom Res 2013;74:206-12.

[118] Xiong J, Lipsitz O, Nasri F, Lui LMW, Gill H, Phan L, Chen-Li D, lacobucci M, Ho R, Majeed A, Mclntyre RS. Impact of COVID-19 pandemic on mental health in the general population: a systematic review. J Affect Disord 2020:277:55-64. 